\title{
INTRODUCTION: FROM THE ARCTIC TO ISTANBUL
}

1. Especially following the 1998 economic crisis, when the ruble was volatile for a number of years, it was common for people to conduct business and refer to large expenses in US dollars.

2. Nasra Shah and Indu Menon (1997) detail some of the policies receiving countries in the Middle East, and particularly Kuwait, had toward women migrant workers in the 1990s. See Mahdavi 2011 for an account of the conditions faced by both women and men labor migrants in Dubai.

3. As a number of shuttle traders recounted, even if women traveled with husbands, if they had different last names they would very likely be denied entry to the UAE. As of 2015 the UAE Embassy indicated on its website (Embassy of the UAE 2015) that those holding passports from fifty-two listed countries were eligible for visas on arrival. Russian citizens (among others) were required to arrange visas in advance of arriving in the UAE, and there were no different policies for men and women or any age restrictions indicated.

4. Throughout the text I refer to the former Soviet Union and the FSU interchangeably.

5. Judging from how often migrants asked me to deliver funds or expensive gold jewelry to relatives, themselves brought funds home, or sent money via other informal channels, it is easy to imagine that as much as half of the total remittances were being transferred informally.

6 . By the early 1990s most post-Soviet citizens could enter Turkey on a one- or twomonth tourist visa issued on arrival. Turkey's relatively permeable border policy, beginning in the 1990s, is linked to Turkey's status as one of the signatories of the Black Sea Economic Co-operation agreement meant to facilitate trade and border crossing in the region; Albania, Armenia, Azerbaijan, Bulgaria, Georgia, Greece, Moldova, Romania, Russia, and Ukraine are also signatories to this agreement (Aktar and Ögelman 1994, 344).

7. "Islamist" is a broad term generally referring to the politicization of Islam, but understood variously. Malise Ruthven writes of "Islamism" as the "ideologization" of Islam in terms of politics, where some symbols from the "historical repertoire of Islam" get deployed, "just as communism ideologizes the reality of the commune, socialism the social, and fascism the ancient symbol of Roman consular authority. Islamism is not Islam . . . it is important to distinguish between them" $(2012,26)$. In Turkey since the late 1990s a growing number of people have come to equate the term "Islamist" with a "revival of civic life, incorporating into the political process conservative women" and with a "challenge to the monopoly on urbanism and modernism" held for decades by Turks defining themselves as secular, Westernized, and urban (White 2004, 149; see also White 2002; Vojdik 2010).

8. Post-Soviet labor migration in the twenty-first century spans a large number of countries, with significant concentrations of people in Israel and Western Europe, especially Spain and Italy (Golden 2003; Solari 2014), and across Asia, including in India and South Korea. It became popular in the early 2000s for women from the Russian Far East (e.g., Vladivostok and Khabarovsk) to seek work in South Korea, Japan, and China, and these destinations have also appealed to women labor migrants from Moldova 
(Subbotina 2005, 179; Bloch 2009). In addition to low-paid labor migrants, from the 1990s onward there has been a steady stream of highly skilled migrants securing work in their fields of expertise and leaving the region of the FSU (Kuznetsov 1995).

9. Dramatic inflation and a fall in the Turkish lira accompanied the economic crisis of 2000; the Turkish lira was devalued from 680,000 lira to $\$ 1$ to $1,200,000$ lira to $\$ 1$. However, from 2002 to 2011 Turkey's economy grew about 7.5 percent annually (Taşpınar 2012).

10. In the absence of reliable data on undocumented migrants, police apprehensions reflect something of the diversity of the migrants coming from the former Soviet Union and Eastern Europe. Between 1996 and 2006, Moldovans were apprehended more than any other group of migrants from the former Soviet Union; Ahmet İçduygu and Deniz Yükseker (2012, 443-48) provide approximate numbers for the countries with the highest level of apprehensions as follows: Moldova $(53,000)$, Romania $(23,000)$, Georgia $(18,000)$, Ukraine $(18,000)$, and the Russian Federation $(18,000)$.

For the almost 620,000 irregular migrants apprehended in Turkey in this period, İçduygu and Yükseker $(2012,444)$ distinguish between two categories of transit migrants, those they call "irregular circular labor migrants," which they identify as coming from the former Soviet Union and Eastern Europe, and asylum seekers, coming from a wide range of countries and making up 52 percent of the total transit migrants $(2012,443,448)$. With the escalation of civil war in Syria since 2014, asylum seekers in Turkey have been overwelmingly from Syria; as of April 2017, of the more than 5 million people registered as refugees fleeing Syria, nearly 3 million were registered in Turkey (UNHCR 2017).

11. Bollywood is only the latest version of popular Indian film in the former Soviet Union, but classic Indian film also continues to resonate with many people in the FSU. For instance, see Bollywood's Raj 2013.

12. A growing number of women from former Soviet states have found work as entertainers in India. According to Indian police, as of 2014 there were at least 3,500 women from former Soviet states employed as sex workers in Delhi (Femen 2012).

13. A select group of people were able to take part in the tightly regulated travel from the Soviet Union to countries outside the socialist bloc. However, travel between socialist bloc countries was widespread and ranged from student work brigades to conference attendance to organized tours; in addition, mobility from socialist bloc countries into the Soviet Union, especially for the purpose of education, was extensive (Matusevich 2007). Travel within the Soviet Union was very popular and frequently features in nostalgic accounts; see Gorsuch and Koenker 2006 on the subject of travel within Soviet republics, as well as beyond the borders of the Soviet Union, and the role of this travel in shaping Soviet perceptions of mobility, identity, and social stature.

14. Throughout the text I use "shuttle trader" and "trader" interchangeably.

15. After the brief window of virtually unregulated trade (1991-1993), Russian government restrictions on shuttle traders, limiting the amount of untaxed goods that could be brought into Russia to $\$ 1,000$ and 50 kilograms, or roughly two suitcases (Nikitina 1996), along with the Russian economic crisis of 1998, caused a sharp downturn in trade. However, by 2013 Russia was one of Turkey's largest sources of export revenue overall, at nearly 7 billion dollars annually, or 4.6 percent of total export revenue. Only Germany, Iraq, and Great Britain provided more revenue, with exports making up about 13.7, 11.9, and 8.8 billion dollars (or 9 percent, 7.9 percent, and 5.8 percent), respectively (Turkstat 2016). From 2006 to 2014 Turkey also relied on Russia more than any other country for imports, with 10-16 percent of all imports coming from Russia annually; Germany and China were the next most significant sources for imports.

16. According to Nicholas Barr, the proportion of registered unemployed women shifted somewhat as women dropped out of the official labor market in large numbers 
and stopped being counted in employment data (1994, 167-68). However, Sarah Ashwin and Elaine Bowers argue that women may simply have registered more often, and that there is a significant difference between data on the "registered unemployed" and survey data, as well as significant variation by region and levels of white-collar employment $(1997,23-24,35)$.

17. Cooper provides a productive critique of how the term "modernity" has been deployed, and he advocates for "a historical practice sensitive to the different ways people frame the relationship of past, present, and future, an understanding of the situations and conjunctures that enable and disable particular representations, and a focus on process and causation in the past and on choice, political organization, responsibility and accountability in the future" $(1999,149)$.

18. Douglas Rogers and Katherine Verdery also helpfully demarcate "postsocialist" to mean: "those countries that had been dominated by Communist parties and 'command economies' with socialized property forms, but that after 1989-1991 saw these forms decentralized and pluralized" $(2013,439)$.

19. Taking into account critical perspectives on the term "postsocialism" (or "postsocialism"), throughout the book I use "postsocialist" and "post-Soviet" to refer to a similar set of social relations, with "post-Soviet" as a subset of "postsocialist." I have chosen to use the spelling of "postsocialist/postsocialism" over a hyphenated variant to underscore this set of social relations as distinctive, and not just another in a long line of "post-" eras. Nevertheless, I am cognizant of the critique of some scholars that patterns which may appear "socialist" are not really; they could be "direct responses to the new market initiatives, produced by them, rather than remnants of an older mentality ... people's responses ... may appear as holdovers precisely because they employ a language and symbols adapted from previous orders" (Burawoy and Verdery 1999, 2).

20. I define former socialist or "emergent capitalist" or neocapitalist regions of the world—such as Vietnam, China, and the former Soviet Union-as places where under socialism labor was valued as something that produced an end product of use to the broader society. As Elizabeth Dunn writes about a Polish factory undergoing privatization, the employees viewed the firm as "more than an engine to make profit or even to make products. It was the heart of a social community.... Under socialism it was the vehicle through which the state carried out its moral obligation to care for its citizens" $(2004,46)$.

21. Here and elsewhere I borrow from Nancy Ries's formulation "newly capitalist" $(2002,283)$ to avoid a static, binary portrayal of socialist and postsocialist Russia and to suggest the distinct experience of recent capitalist processes in Russia. This analysis is also inspired by Aihwa Ong's (1999) important discussion of multiple capitalisms.

22. There is a vast literature on affect and, increasingly, a vibrant feminist critique of distinctions made between "affect" and "emotion," the possibility for a productive tension between the two, and the pitfalls of attempting an analysis that combines both. Carolyn Pedwell and Anne Whitehead helpfully analyze these terms and their use in feminist theorizing, also tracing how the "affective turn" emerged in response to the 1980s "textual turn" and its overemphasis on the discursive $(2012,116)$. Pedwell and Whitehead pose a key question: Does affect theory's aim to direct attention to forces beyond emotion that unconsciously work on people ultimately become a depoliticized project? In other words, if people are not aware of the forces that are working on them, what are the possibilities for social transformation?

23. Research revolving around discourse and forms of oral tradition has defined this scholarship, with work on expressions of anger in Papua New Guinea (Rosaldo 1980), honor among the Bedouin in Egypt (Abu-Lughod 1986), and love in Sri Lanka (Trawick 1990 ). For a review of the anthropological literature on emotion prior to the early 2000 s, see Wilce 2004. 
24. The definition of trafficking has evolved over the years, but the UN Protocol, in fact, emphasizes how a wide range of people - not excluding men, not limited to those involved in sex work, and including those who are legally located in a country-could be considered trafficked. As the Protocol states, to be trafficked hinges on "the act of recruiting, harbouring, transporting, providing, or obtaining a person for compelled labor or commercial sex acts through the use of force, fraud, or coercion" (see Madhavi 2011, 16-7). However, while the United Nations Palermo Protocol and the United States' Victims of Trafficking and Violence Protection Act (TVPA), passed in 2000-two of the most important anti-trafficking measures to be forged-claim to have an explicitly broad definition of trafficking, the assessment of anti-trafficking measures continues to focus heavily on women sex workers (see Vance 2011; US Department of State 2012a).

25. For instance, one long-established anti-trafficking organization, the Coalition Against Trafficking in Women (CATW), lumps prostitution with trafficking and notes that "prostitution and trafficking ... [are] major human rights violations of women." In situating its work, CATW (2011) writes, "Our challenge, in opposition to the enormous power and resources of the sex industry that portrays prostitution as sexual liberation, work or even glamorous, has been to make the harm of prostitution visible."

26. For instance, without any clear means of substantiating the claim, in the late 1990s and early 2000s one figure repeatedly occurred in sources indicating that two-thirds of an estimated five hundred thousand women annually trafficked for prostitution to forty to fifty countries across the world came from Eastern Europe and the former Soviet Union (see Hughes 2002, 5).

27. A number of documentary and docudrama films were produced in the 2000s on the subject of trafficking. These include Trafficking Cinderella (2001), made in Canada with funds from the Open Society Institute, and The Price of Sex (2011), first aired as Trafficking in Women in October 2005 by the Canadian Broadcasting Corporation. The feature film Lilya 4-Ever (2002), a Swedish/Danish joint production, also had a wide viewership.

28. One source indicates that law agencies globally reported trafficking as affecting over forty-one thousand individuals in 2011 (USAID 2012a).

29. The constellation of feminism that Elizabeth Bernstein (2012) calls "carceral feminism" focuses on anti-prostitution and is staunchly in support of anti-trafficking measures that expand the powers of the state; adherents support intensifying policing to control trafficking in women, something they equate with prostitution/sex work.

30. As Donna Guy writes, "For many Europeans it was inconceivable that their female compatriots would willingly submit to sexual intercourse with foreign, racially varied men ... so European women in foreign bordellos were construed as 'white slaves' ... and the campaign to rescue them became a glorious battle pitting civilization at home against barbarism beyond" $(2000,74)$.

31. In writing about the history of prostitution and its regulation in Argentina, Guy $(1991,7)$ describes how European women fled poverty and sometimes religious persecution to seek a means of survival abroad; these women "filled Buenos Aires bordellos" at the peak of outmigration from Europe, from the 1870s to the beginning of the First World War.

32. The United States Trafficking Victims Protection Act (TVPA) of 2000 and subsequent Reauthorization Acts $(2003,2008$, and 2013) were passed with the intention of combatting trafficking in persons worldwide, with the annual Trafficking in Persons reports (TIP) assessing each country's anti-trafficking efforts as a central component (see Mahdavi 2011, 16-21; Cheng and Kim 2014). The TIP reports, issued by the US Department of State, rate each country on a scale from Tier 1 to Tier 3 . Tier 1 countries (consistently relatively wealthy countries, such as Sweden and the United Kingdom) are deemed to have adequate countertrafficking measures in place, while Tier 3 countries (consistently less wealthy countries) are deemed to be inadequately addressing the issue of trafficking. A Tier 2 "provisional" rating 
is meant to signal that a country needs to apply more effort to address concerns about trafficking. Countries identified as Tier 3 are then subject to US sanctions in the form of losing favored trade status and/or nonhumanitarian aid. Scholars have suggested that these ratings could have more to do with US foreign policy than any actual reflection of degrees of trafficking in a given location (Mahdavi 2011, 19; Cheng 2010, 201-2).

33. By 2014 the TIP report continued to classify Turkey as a "Tier 2" country, noting that Turkey "does not fully comply with the minimum standards for the elimination of trafficking" (US Department of State 2014, 383).

34 . As a reflection of its growing mandate, as staff at the IOM office in Istanbul told me in 2007, in just two years, between 2004 and 2006, the IOM offices in Turkey expanded from two to twenty people, located in both Istanbul and Ankara. The IOM has also been instrumental in identifying (and partially financing) several Turkish NGO partners to provide police training in how to identify trafficking victims, to create and administer shelters for women identified as trafficked, and to provide assistance in returning those identified as victims of trafficking to their home countries. See Keough 2015 for a thorough discussion of discourses on trafficking in Moldova.

35. Each purchase of clothing was made in batches of five or seven sizes, so for instance a batch of pants would be in small (S), medium (M), Large (L), Extra Large (XL), and Extra Extra Large (XXL); shuttle traders would ask for a specific number of batches. For instance, two batches would result in ten shirts being purchased. As a reflection of the ways in which the shuttle traders acquired specialized knowledge, Olga and other shuttle traders would incorporate the English inflected labels and ask shopkeepers for a shirt in size "S-ka" or "L-ka" instead of "small" or "large" in Russian (malen'kii or bol'shoi). The goods, which were destined for a global market, including Russia but also Europe and North America, were most often labeled in English, or sometimes by number (e.g., 4, 6, 8, 10, etc. for women's clothing destined for North America, or 36, 38, 40, 42, etc. for clothing destined for Europe).

36. Ruzhena and Udara were adamant that they wanted me to use their real names, a request I am honoring here.

37. See Scheper-Hughes 2005 on how disenfranchised people in Europe are linked to a global traffic in human organs, including kidneys.

38. Among Russian speakers from the FSU the term "svoi," meaning "our own" or "one of us," is most often invoked to indicate that a person is in one's social circle or that a thing is particular to a specific circle of connection. Margaret Paxson translates "svoi" as "one's own," and points to the possible concentric circles the term can reference, including extended family, co-villager, or compatriot $(2005,53)$.

39. In part as an effort to attract less attention, in summer I wore loose tunics and trousers with sensible sandals, a look Russian speakers I came to know well sometimes chided me for, suggesting that I was too young to forgo wearing more revealing clothing and stylish footwear. Likewise, some Turkish friends who comfortably dressed in miniskirts or light strappy sundresses poked fun at me, saying that my attire implicitly lent support to Islamist factions and their preference for women to dress modestly.

40. Ahmet İçduygu notes that in Turkey in 2005 there were 132,000 people with residency permits, the document issued for those legally living in Turkey for more than three months, and nearly one-third of the permit holders were from Bulgaria $(2009,288)$. Only 17 percent of the permits were issued for people employed in Turkey, with 19 percent for students and the remaining permits for dependents of the primary permit holders.

\section{CHAPTER 1. MAGNIFICENT CENTURIES AND ECONOMIES OF DESIRE}

1. While The Magnificent Century has been the most popular of the transnationally broadcast Turkish television dramas, more than a hundred other shows are also internationally broadcast in either dubbed or subtitled form throughout the Balkans, Latin 
America, the Middle East, and Asia (Soap Opera Diplomacy 2013). As of 2016 The Magnificent Century was distinctive as the only television drama that featured a woman historical figure who hails from a region of the former Soviet Union.

2. The earliest export of Turkish soap operas dates to 2001, when they were first sent to Central Asian countries, particularly Kazakhstan and Uzbekistan (Balli et al. 2013, 181). Viewership of Turkey's telenovelas expanded significantly in the early 2000s, in particular in Arab countries. Some reflect that this "media flow" may be explained by a number of factors, including widespread linguistic affinities, a common Muslim value system in at least twenty countries, the use of alluring Turkish locations for filming, such as the Bosphorus, and the common inclusion of libidinous and/or professional women in the series (Buccianti 2010). In 2014 The Magnificent Century also premiered in the United States via MundoFox Broadcasting (Global Agency 2014).

3. Outside Turkey some who see the telenovela as celebrating Turkish dominance in the region have also contested it. For instance, in one Internet forum revolving around things Slavic, in September 2012 the string for "Bulgaria" had a substring of "Turkish Neo-Ottoman TV Series," and the posts were dominated by a sentiment of alarm about the widespread fascination with the television series. As one person writes, "It's all part of the same plan, to make south Slavs more opened towards Turks. TV stations in Bosnia, Serbia and Croatia are full of Turkish soap-operas. This show about sultan Süleyman is just another in line but certainly the worst one in terms of Turkish propaganda.... I am especially mad at south Slavs which approve this show in our areas and thus take a ${ }^{\star * \star *}$ on all the suffering our peoples had during the Turkish occupation" (Slavorum 2012).

4. Hürrem is most often referred to as "Roxelana" by Russian speakers, but depending on the source, she is also sometimes referred to as "Anastasia" or "la Russa," in reference to her origins (Freely 1996, 194).

5. Hürrem may have originally come from Rohatyn, Ukraine, but this is difficult to confirm given the paucity of sources (Peirce 1993, 59). Few documents exist on Hürrem's life, with the exception of some references gleaned from Venetian and French diplomats' correspondence, comments made by prisoners escaped from Ottoman prisons, merchants' records, and letters composed by Hürrem and addressed to Süleyman, although there are no known surviving letters written by Süleyman to Hürrem (Peirce 2015).

6. Alexandra Lisowska was known as "Roxelana" perhaps because of the Medieval Latin name for Rus'-Ukraine or due to a Polish term meaning "Ruthenian maiden," a reference to Alexandra's possible origins in a part of Poland (present-day Ukraine) where Ruthenians have been historically concentrated, even as the region has witnessed the expansion and contraction of more than one empire over nearly six hundred years (Peirce 1993, 58). The group most often known as "Ruthenian" in English is also referred to as "Rusyn." Since the Middle Ages the Rusyns have recognized a homeland in what some call the heart of Europe, in territory ruled at different points by many different governments and empires (Magosci 1995). Interestingly, this homeland is also seen by some as the site of a significant divide between the Catholic West and the Orthodox East (Picchio 1984). The Rusyns have never had their own state, but at different points in history they have mobilized for their own political representation and even distinct nationhood. According to Paul Magosci (1995), most often they allied themselves strategically as Russian or Ukrainian. Linguistically, Rusyns are Eastern Slavs, but whether they should be seen as closer to Russians or Ukrainians is much debated.

7. In Byzantine times, as well, women of humble origins sometimes rose to celebrated positions of power. One of the most famous women with a courtesan past was Empress Theodora, married to Byzantine Emperor Justinian once he ascended the throne in 527AD (Dauphin 1996, 5).

8. Circassia came to be widely known as the homeland of "Circassian beauties." At least since the seventeenth century the Orientalist idea of a "Circassian beauty," or an 
idealization of Circassian women as embodying the pinnacle of aesthetic beauty, appeared in European art; in the eighteenth century with the growing encroachment of the Russian Empire on the area of Circassia, the notion of a "Circassian beauty" became even further entrenched in European art and literature, as well as in the popular Turkish imagination (Doğan 2011, 84). For further reflection on the links between gender, nation, and the Circassian diaspora, see Doğan 2011.

9. The woman known as "Roxelana" and "La Russa" in Western sources is referred to officially as Haseki Hürrem Sultan in Turkish sources, or more popularly as just Hürrem. Supposedly Alexandra was given the name of "Hürrem" because of her sunny demeanor; in Turkish, Hürrem means "the cheerful one." Leslie Peirce provides a fascinating discussion of the term haseki, meaning the "sultan's favorite," and describes it as a "candidly political role" that shifted over time $(1993,104-12)$. Peirce also lucidly traces how sultan emerged as a title carried by both male and female Ottomans, and at times favorite concubines, in a growing "legitimating discourse as the Ottoman dynasty advanced ever-greater claims to prominence in the Islamic world" $(1993,18)$. Hürrem Sultan died in April 1558, and although in her lifetime she wielded enormous power, surprisingly little is known about her (Peirce 2015).

10. A second monument to Hürrem, a large public bath, was also built at a prominent axis of the imperial city. It was located near the royal palace, the Aya Sofya (the churchturned-mosque then mosque-turned-museum, then, in 2016, museum-turned-mosque), and the Hippodrome (Peirce 1993, 203; First Call 2016).

11. The renowned Ottoman architect Mimar Sinan was commissioned to design the mosque complex, which included a mosque, school, college, soup kitchen, hospital, and fountain. In 2010 there were plans to allocate a portion of the complex for a museum dedicated to Mimar Sinan (Demir and Gamm 2010).

12. In one analysis that pivots around desire as a commodity but shortchanges relevant historical context, performance, or polyvalent meanings that might be brought to intimate encounters, Anna Agathangelou argues that "white but not quite" men in Cyprus in the 1990s and early 2000s looked to "white but not quite" women, who were predominantly from the former Soviet Union and Eastern Europe, as a means of gaining status for themselves and for their states $(2004,71)$.

13. Pelkmans (2006) describes the measures people would go to in trying to communicate across the closed border and provides a fascinating ethnographic account of the history of transborder connections between Georgia and Turkey, including the paradoxical post-Soviet slowing down of flows and cross-border connections for some, and the increased opportunities for others.

14. This concept of kul'tura, sometimes translated as "culture" and other times as "civilization," circulated widely in the Soviet Union and connoted a particular cultural hierarchy, including a high regard for literature, liberal ideals of gender equality, and a respect for education. The concept was also often implicitly linked to an understanding of different cultural groups as being at different points on an evolutionary scale where an urban, industrialized Europe was seen as the pinnacle. There is a large volume of writing on this concept as it emerged in Soviet society (see Grant 1995). In her Mastering the Art of Soviet Cooking: A Memoir of Food and Longing, Anya Von Bremzen (2013) discusses how by the 1930s acquiring kul'turnost' or "becoming cultured" came to revolve around trappings of "high" culture in the form of attending the theater or opera and being well versed in the classics of European literature.

15. Michael Reynolds $(2011,6)$ argues that interstate competition in the early twentieth century complicated political allegiances in eastern Anatolia, with Kurds and Armenians especially caught between struggles for Ottoman and Russian empire building.

16. As Vera Tolz vividly recounts, by the late nineteenth century a lively scholarly debate emerged, especially in Russia and Germany, around the geographic, political, and 
cultural constructs of "East" and "West" (2011, 47-68). Following the horrors of the First World War, when the superiority of "Western" societies was widely questioned, Russian scholars fundamentally repositioned how they thought about "East," "West," "Europe" and "Asia"; for instance, one school of thought in Russia emerged holding that Russia was uniquely positioned at the "convergence" of East and West, and yet another group denied the existence of any meaningful differences between European and Asian traditions (Tolz 2011, 56-57).

17. The first time the Rus' sailed down the River Dnieper and across the Black Sea to threaten Constantinople, their appearance apparently terrified the Byzantines, whose reaction was to send out a missionary tasked with converting them to Christianity (Herrin 2007, 137).

18. In the most significant treaty, signed following the Rus' attack on Constantinople in 987, Vladimir of Kiev secured a promise of betrothal to Anna Porphyrogenita, the sister of Eastern Roman Emperors Basil II and Constantine VIII. The treaty also stipulated that the Rus' would send six thousand mercenaries to be incorporated into the Byzantine defense forces, including into the Varangian Guard, an elite group of non-Byzantine warriors safeguarding the emperor. While betrothal to an "authentically imperial" bride, or a porphyrogenita, solidified Vladimir's status in his nascent state, and the contribution of warriors meant that Byzantium became at least in part dependent on military reinforcements from the Rus', for Byzantium the treaty was crucial because it secured stability in the face of civil war (Herrin 2007, 16,213; Bréhier 1977, 149). This was not the last time an arrangement combining marital and military solutions for brokering peace and commercial interests was to bring the Rus' and Byzantium together, but the 987 treaty portended fundamental transformations for Rus' society.

19. Vladimir also ordered the Rus' adoption of an early version of Cyrillic script, a system derived by the Bulgarian missionaries Cyril and Methodius, and probably the earliest form of writing known to the Rus'.

20. In 1473 Tsar Ivan III married Sophia, the niece of the last Byzantine emperor, and Russia increasingly adopted ritual practices borrowed from Byzantium, as well as the Byzantine double-headed eagle as the state symbol. By the middle of the sixteenth century, when Ivan IV (Ivan the Terrible) was crowned as tsar (in 1547), Muscovite Russia is said to have fashioned itself as the seat of the last authentic Orthodoxy, and Moscow as the "Third Rome." However, Marshall Poe (2001) argues that this "modern historical myth" was propagated in the second half of the nineteenth century. In 1589 the patriarch of Constantinople did establish Moscow as a patriarchate, making it the fifth of the Oriental sees, after the patriarchates of Constantinople, Alexandria, Antioch, and Jerusalem (Ware 1993, 112-16).

21. When in 1783 the Crimean Khanate in Russia was officially dissolved by Catherine the Great, a significant part of the Crimean Tatars moved to the Ottoman Empire. Although, as Reynolds cogently shows in his discussion of the rise of a "national idea" in the late nineteenth and early twentieth centuries, Tatars were drawn back to settle in Russia $(2011,47)$.

22. In the second half of the nineteenth century the thousands of Greeks and other non-Muslims who arrived to work in the city were mostly men. These new non-Muslim immigrants could often be identified by their kepele, a special European brimmed hat that distinguished them from the locals who wore a fur hat (Karpat 1985, 103).

23. Kemal Karpat traces a steady increase in the percentage of Istanbul's population that was Muslim from 1880 to 1900 . He writes how "by the end of the century the colonization process was reversed, and Istanbul had become once more Islamic and Turkish in character, just as it had been from the fifteenth through the early nineteenth century" $(1985,86)$. Between 1844 and 1880 , roughly 50 percent, and very likely much less, of the 
population was Muslim; as Karpat notes, the 1844 census was conducted right after a large inflow of non-Muslims into Istanbul. However, these people would not have been registered, and therefore were not paying taxes, so would not have been included in the census $(1985,103)$.

24. Accordingly, whereas in 1913 one in five citizens in the territory that is today Turkey was Christian, by 1923 just one in forty citizens in the same territory was Christian (Keyder 2005, 5-6). This trend continued throughout the twentieth century, and as of the mid-2000s, 99 percent of Turks identified as Muslim (İçduygu et al. 2010, 360).

25. When General Wrangel, or Pyotr Nikolaevich Wrangel, evacuated Crimea in November 1920, 126 boats with 145,693 Russians on board arrived in Istanbul (Mansel 1995, 398).

26. A building in the popular present-day Beyoğlu, the "Flower Passage" (çiçek passaj), received its name in reference to the Russian women who sold flowers there in the 1920s (Mansel 1995, 399).

27. Charles King notes that there were 175 brothels operating throughout Istanbul in the early years following the First World War, and as many as 4,500 women employed in these; while Greek and Armenian women were the majority, Russian women were estimated to make up a quarter of those employed in the brothels $(2014,148-49)$.

28. According to one source the Modern Women's Club called press conferences in 1922 where it demanded that "Russian" women be deported (Deleon 1995, 35).

29. Not all literary treatments of this lively nightlife cast it as simply dissolute. Paul Haurigot's Acide russique, published in French (1929) and later in Turkish, portrays the love of a Frenchman for a Russian woman working in an Istanbul nightclub.

30. Those Russians (and others) who received Turkish citizenship as a result of Law 1312 adopted a Turkish surname. Those 986 Russians who were granted citizenship in 1934, according to the May 29 decree, were not required to take up a Turkish surname or convert to Islam, terms that were not enjoyed by any other ethnic community in the country at the time (Çağaptay 2006, 75-77).

31. The November 2, 1937, government order refused refugees from the USSR entry, but it also stipulated that in cases of those who had managed to enter the country, they were to be "resettled at least 50 kilometers away from the Soviet border." A 1933 government order sent to the Turkish provinces along the Soviet border demanded that those of "non-Turkish race ... ought to be denied asylum and returned to their places of origin" (Çağaptay 2006, 97-98). The early Republican Turkish government also distinguished between Muslims, in particular Kurds; depending on perceived nationalist sentiments among these groups, as well as shifting political strategy, the government treated them differently, a practice Reynolds $(2011,52-70)$ links to the emergence of the nationalist ideas growing throughout the region in the late nineteenth and early twentieth centuries.

32. At the same time all twelve NATO countries combined spent an average of 6.6 percent of their national budgets on defense (Machado 2007, 94).

33. Cevat Tosun argues that Turkey expanded its tourism sector primarily as a means of acquiring foreign currency, and this pressing need compelled planners to privilege profit over considerations for sustainable development (2001,291). Tosun also points out that the 1982 "Tourism Encouragement Law No. 2634" accelerated mass tourism development in a number of ways, including by allowing appropriation of state land for hotel development, by facilitating the employment of foreigners, and by encouraging vocational education related to tourism $(2001,291)$.

34. In 2011 Turkey ranked as the sixth most visited country in the world, with 29 million tourists; 4.8 million of these tourists were German (UNWTO 2012, 6-7). In the same year Russian citizens made up the second most numerous group of tourists visiting 
Turkey, with 3.5 million Russians arriving as tourists (Russian Tourists 2012). In 2011 Russia also became the seventh highest ranked country in the world for tourism dollars being expended; Russians spent 33 billion dollars on tourism, up from 27 billion in 2010 (UNWTO 2012, 13).

35. While in 2007 the service sector made up 59.3 percent of the gross domestic product (GDP), by 2011 the service sector, including tourism, accounted for 65 percent of the GDP (CIA World Fact Book 2009).

36. Turkish government enthusiasm for the economic prospects associated with faith tourism does not necessarily insure that all churches will be preserved in the same way, however, and a particular tension around designations as "church" vs. "museum" continue to determine whether Christian pilgrims are permitted to pray at some sites (St. Nicholas Center 2012; Pravoslavie.RU 2012; First Call 2016).

37. In 2011 the only year-round residents of the Monastery of St. George were the caretaker, a Greek-Turkish Christian man, and his Turkish wife, and forty-eight Alevi Sh'ia Muslim families who were working the land (Lewis 2011).

38. Aya Yorgi Garibi, or the Monastery of St. George, is one of the sites currently under the control of the Turkish government that the Greek Orthodox Church is requesting be returned to it (Orthodox Church 2010). In the aftermath of the First World War and the breakup of the Ottoman Empire, leading to Turkey and Greece carrying out massive population exchanges, the Turkish authorities seized control of properties, ultimately placing twenty-four Greek Orthodox properties under the control of the Foundations General Directorate, a state organization dealing with confiscated properties owned by 147 foundations originally run by minorities. On the Foundations General Directorate, see Kurban and Tsitselikis 2010.

39. St. Pantaleimon, and one other small Russian Orthodox Church, St. Andrew's, was originally built as a chapel to serve Russian pilgrims staying in the attached dormitories as they were en route to Mt. Athos; the churches were most visited in the early 1920s when the dormitories housed Russians fleeing the Russian Revolution. For one literary treatment of the handful of Russian families that remained in Istanbul from the 1920s onward, see Barbara Nadel's detective thriller Belshazzar's Daughter (1999). For an eclectic, popular history of this community, see Deleon's The White Russians in Istanbul (1995).

40. From 2003 to 2006 Turkey's reliance on Russian sources of gas nearly doubled (Kınıklığlu and Morkva 2007, 540). However, Turkey also sought to avoid dependence on Russia, and Turkey has entertained a number of large-scale pipeline projects that would move Caspian gas via Georgia (bypassing Russia) and via Turkey to Central Europe (Weitz 2010, 66-67; EuroActiv 2012).

41. Although in 2010 there was substantial bilateral investment, with Russian investments in Turkey at $\$ 6$ billion and Turkish investments in Russia at $\$ 4$ billion, there was still a substantial trade imbalance. In the mid-2000s Turkey was $\$ 7$ billion in debt to Russia (Kınıklığlu and Morkva 2007, 538), and for a number of years Russia was Turkey's largest trade partner; by 2010 Turkey ranked as the seventh largest trade partner for Russia (Weitz 2010, 71).

42. Among other changes, as of 2013 a number of countries were granted visa-free entry into Turkey with the following terms: citizens of Moldova could remain up to 90 days, "within 180 days, starting from the date of the first entry"; citizens of Russia and Ukraine could remain up to 60 days; and citizens of Central Asian countries such as Tajikistan, Uzbekistan, and Kazakhstan could remain up to 30 days. Although this is an important change making it easier for migrants to remain legally in Turkey, these tourist visas do not allow migrants to work (Turkish Ministry of Foreign Affairs 2016). 
43. Other organizations have also played roles in these policies, including a Prime Ministry, President of Turks Abroad and Related Communities established in 2010, and the Black Sea Economic Cooperation Organization (BSECO) established in 1999.

44. As of 2008 the Fethullah Gulen movement had created a network of more than 800 elementary to college-level educational institutions in 160 countries. The Gulen movement, headed up by a Turkish Muslim preacher and political figure who has been based in the United States since 1999, claims to promote "moderate Islam rooted in modern life" (Hudson 2008; Putz 2016). In July 2016, in retaliation for a failed coup attempt that the Turkish government suspected the Gulen movement of orchestrating, more than three hundred Gulen-supported schools within Turkey were immediately closed, and tens of thousands of civic employees in fields ranging from education to media to social services were fired because they were perceived to be sympathetic to the Gulen movement.

45. For comparison, the International Labor Organization (ILO) reports that in 2002 in the United States women comprised 54 percent of professionals, and in Switzerland, 42 percent (Countries 2002). The Turkish Statistical Institute notes that in 2011 while the fertility rate was as high as 3.4 in some regions (eastern Anatolia), in Istanbul it was 1.7 per 1,000 women; also, for 15-19 year-olds, the rate was 20 per 1,000 in Istanbul, and 45 per 1,000 in eastern Anatolia (Turkstat 2012). The Human Development Index shows that overall for 2015 in Turkey 30.9 per 1,000 women in the 15-19 year-old age group had given birth, and this number dropped from 44.8 in 2005. By comparison, Moldova's rates were at 39.3 per 1,000 in 2015 , up from 37.4 per 1,000 in 2005 , while Russia's were 25.7 per 1,000 in 2015, down from 27.6 per 1,000 in 2005 (UNDP 2016).

46. The Human Development Index (HDI), produced by the United Nations Development Programme (UNDP), regularly assesses countries globally on a number of metrics, including gender equality. The Gender Inequality Indicator (GII) measures the "loss to achievements in reproductive health, empowerment, and access to the formal labor market due to gender inequalities." In 2014 Turkey ranked 72 out of the 188 countries rated, alongside such countries as Mexico, Venezuela, and Sri Lanka (UNDP 2016).

47. The World Economic Forum employs what it calls a "Gender Gap Index" measured on the basis of four categories where women's situation is analyzed: health, education, economic participation, and political empowerment. In 2015 Turkey placed 130 out of 145 countries ranked; with a score of .62 on a scale of 0 to 1 , Turkey had one of the worst gender gaps recorded in the world (World Economic Forum 2015). Benin and Guinea also had similar scores, ranking at 129 and 131, respectively.

48. Thomas Naylor suggests that the military coup in Turkey in 1981 was, in part, brought about by the austerity measures imposed by the IMF. Naylor also traces an astounding set of links between drug circuits, weapon supplies, and Turkey as a strategic country for US political aims in the region (2004, 92-105).

49. These rural enclaves located at urban peripheries, known as gecekondu, burgeoned since the 1960s and have significantly shaped urban politics in Turkey. See Karpat 2004 on the phenomenon of these rural migrant settlements and the extensive scholarship dedicated to studying them. Also see İçduygu et al. 2013 for a cogent analysis examining Turkish rural to urban migration, emigration, and return migration.

50. Ayşe Akalin (2007) notes that in contrast to migrant women from the former Soviet Union, in part due to widespread cultural expectations for women to remain close to home, Turkish migrant women are rarely employed in positions that take them far away from home or require them to live at an employer's house. Furthermore, the $\$ 700-\$ 800$ per month demanded by Turkish women employed as domestic workers in the mid-2000s contributed to the demand for the more flexible, non-Turkish domestic 
workers who would work longer hours, agree to be employed as live-ins, and work for \$450-500 per month (Akalin 2007, 224).

51. In the mid-2000s, 22.8 percent of women were employed outside the household (Müftüler-Baç 2012).

52. In 2011 one Turkish NGO reported that 42 percent of women in Turkey had experienced domestic abuse or sexual harassment, and between 2002 and 2007 the number of women murdered increased from 66 to 953 per year (Jones 2011). In an essay critiquing the category of so-called "honor killings" and the "tradition effect," Dicle Koğacioğlu notes that between 1994 and 1996 fifty-three women were targets of such murders (2004, 118); Koğacıoglu argues for avoiding the idea of "honor killings" since this locates the causes of violence against women in "tradition," allowing a critique of the political and economic causes of such violence to go unexamined.

53. A vibrant women's movement, including a political party committed to women's rights, the Women's People's Party (Kadinlar Halk Firkasi), emerged in this era but was short-lived. As the only political organization founded by women in early Republican Turkey, it was disbanded in 1934 because it was seen as superfluous to the primary aims of the new nation (Parla 2001, 73). This mirrors the fate of the Soviet Union's Women's Commissariat (Zhenskii sovet or Zhenotdel), which was disbanded in 1930 with the retrenchment of revolutionary gender ideals (Goldman 1993, 338).

54. One of the forms of gender inequality that is enshrined in law involves the Penal Code. Until 2005, in the Penal Code, all assaults against women fell under a section of law that was particular only to women. Assaults generally fell under the category of "Felonies against Individuals," except in the case of women, when assaults were charged under the section of "Felonies against Public Decency and Family Order" (Parla 2001, 77; Miller 2007). With the 2005 Penal Code, crimes committed against women were classified along with crimes committed against any individual instead of being classed with crimes related to "public decency" or "family" (Müftüler-Baç 2012).

55. Sentiments about virginity, however, vary widely depending on urban and rural locations, but especially by age, class trajectory, and gender. In her survey of 360 upwardly mobile youth at Boğaziçi University in Istanbul, Gul Ozyegin found that 61 percent of all students whose mothers had only completed elementary school said they wanted to marry a "virgin," whereas 18 percent of those with mothers who had gone to university sought a virgin as a spouse. Fifty-one percent of male students responded affirmatively to the statement "I want to marry a virgin," but only 15 percent of female students said they preferred to marry a virgin $(2015,40,43)$. Likewise, in a survey of university students in Diyarbakir (southeastern Turkey), male students found premarital sex less acceptable than female students did; men generally expected their future wives to be virgins, while female students largely said it did not matter to them if their future husbands were virgins (Eşsizoğlu et al. 2011, 146). See also Göksel 2009.

56. These exams have a historical precedent dating from the system of regulated brothels introduced under Abdulhamid II in 1884, when brothels came to be operated with a government-issued license, and regular inspections were conducted by police and health officials. After this system fell apart during the First World War, the French contingent of Allied occupation forces in Istanbul was tasked with overseeing and licensing brothels. In 1933, following international pressure, including a 1927 series of reports by the League of Nations that framed Istanbul as a prime center of "trafficking" in women, the Turkish government created a new state bureaucracy, the Ministry of Health and Social Assistance, to oversee the licensing and inspection of brothels and the regulation of sex workers (King $2014,147-49)$. As of 2013 the ministry continued to carry out this mandate in designated neighborhoods (Evered and Evered 2013). 
57. Drawing an extreme comparison, he equated both abortions and caesareans to a then recent massacre of Kurds at the Turkish-Iraqi border (Sehlikoğlu 2013).

\section{CHAPTER 2: GENDER, LABOR, AND EMOTION IN A GLOBAL ECONOMY}

1. There is a discrete literature focused on women engaged in small-scale trade, many of whom sell their wares in open-air market stalls, but all of whom deal in relatively small amounts of wares, frequently acting as supplier, stocker, bookkeeper, and salesperson in their businesses. Scholarship on such traders does not employ a uniform set of terminology. For instance, Hill Gates describes the "petty capitalist" women entrepreneurs in Taiwan (1991), Gracia Clark writes about Asante women in Ghana as "market women" (1999), and Florence Babb (2001) describes small-scale trader women as working in the "informal economy." Maria Quiñones (1997) writes about Barbadian "suitcase traders" and "higglers," a term Carla Freeman (2002) also uses in her discussion of Barbadian women moving apparel between New York and home communities. Michel Peraldi (2005) writes that male Algerian suitcase traders who travel to a wide range of destinations, including Istanbul, are referred to as trabendistes in Algeria. Konstantinov (1996) writes of "trader-tourists" to refer to those small-scale traders moving goods between Istanbul and Bulgaria. Humphrey $(2002,88)$ notes that in China, Mongolian shuttle traders are known as gahaichin, or "pig keeper," a pejorative term referring to pastoralists of the steppes but also the huge bales of goods that traders transport; she also indicates that at one point Russian traders in China were known as "vacuum cleaners," since they were thought to buy everything within sight.

2. I am borrowing this terminology from Roger Rouse (1992) who employs the idea of "transnational circuits" to describe the way in which Mexican migrants and negotiated ideals around masculinity, class, and citizenship circulate between southern California and northern Mexico.

3. These three women identified as ethnically Russian, although one of them also had family in Ukraine. However, the women traders I came to know in Istanbul and in a small city located about 60 miles south of Moscow identified with a range of ethnic identitiesincluding Russian, Ukrainian, Belorussian, Moldovan, Gagauz, and Kazakh-and often referred to themselves collectively as "Soviet" (sovetskie).

4. Like many anthropologists studying this region, Humphrey resists the tendency to assume that Russia and other countries in the region are in "transition" to a Westerndefined form of capitalism. She calls for ethnography to focus on the "nontheorized and most various frameworks and values through which people understand the world ... they both inform economic action and create reactions to that action" (1999a, 21).

5. Likewise, for the Russian Federation, the shuttle trade was also crucial; in 1996, for instance, the shuttle trade from all countries to Russia was estimated to account for one-quarter of Russia's total imports, or about $\$ 21.5$ billion (Yenal 2000, 3). In the case of Ukraine, in the mid-1990s the shuttle trade accounted for as much as 20 percent of the shadow economy, which in turn was estimated as being equivalent to as much as 50 percent of Ukraine's formal economy (Ivanova and Buslayeva 1999, 637).

6. Cognac is a type of brandy, named after the town of Cognac, France, and is produced from grapes grown in the region surrounding this town, but "cognac" (koniak) is a type of brandy that was considered a luxury good in the Soviet Union. For brandy to be considered Cognac it must be produced from specific grapes and processed according to legally defined international standards. Several domestically distilled "cognacs" are available in the former Soviet Union, most typically from Moldova and Armenia (Russian Market 2002). Although traders spoke of selling "cognac" in the early days of their travels, they most likely sold Armenian or Moldovan "cognac"/brandy, not the signature French 
Cognac, which, as in other locations globally, in former Soviet locations today is a sign of distinction (Jarrard 2007).

7. For a film portraying women traders in Central Asia, see Ballad of a Trader (2005). I am grateful to Manduhai Buyandelgeriyn for sharing this source.

8. According to other estimates, by 2002, 12 percent of urban Russian households were involved in cross-border trade or labor migration (Badishtova 2002, 83).

9. There are a number of spheres related to shuttle trade; on classifications of trade and trade related work in Russia, see Humphrey 2002, 88-90. As Pernille Hohnen describes for Lithuania $(2003,20)$, in the early 1990s in Russia men and women entered into trade at open-air markets with gender-specific expertise-men sold shoes, tools, and sometimes vehicles, and women concentrated on selling food and clothing that was most often shuttled from Turkey.

10. Like Endre Sik and Claire Wallace (1999), I have translated otkrytye as "openair" in reference to these markets. Although they could also be thought of as "community street markets," traders and vendors often emphasized that the markets were "open" (otkrytye), not "closed" (zakrytye), in direct reference to being outdoors in the "open," without a roof. This was in contrast to the "closed" markets, or what have since come to be referred to as "shopping centers" (torgovye tsentry), located in large enclosed complexes.

11. According to the Turkish Ministry of Tourism, in 1996 about 60 percent of arrivals (5.2 million) came from OECD countries, while about 26 percent (2.2 million) came from East European countries and countries of the former Soviet Union (Tosun 2001, 299).

12. In addition to selling several popular newspapers and tabloids published in Russia (e.g., Moskovskii Komsomolets, SPEED-Info), in the early 2000s kiosks sold the Istanbulbased Russian-language bimonthly newspaper TurPressPanorama; by 2012 kiosks in the neighborhood sold an Istanbul-based bilingual Russian-Turkish bimonthly newspaper, Bosfor.

13. Beginning in the early 1990s Russian-speaking customers were the most visible foreigners in the neighborhood, and Russian served as a lingua franca among most buyers and shop assistants, wholesalers, restauranteurs, and taxi drivers. However, as this garment district attracts a wide range of transnational traders, including from the Middle East, North Africa, and Eastern Europe, it is also common to see businesses, like tour agencies, appealing to clients in signs written in languages other than Russian. In 2013 with the Syrian civil war extending into its fifth year, and nearly three million people seeking refuge in Turkey, Arabic script was increasingly visible in Laleli and Aksaray. On Syrians in Istanbul, see Genç and Özdemirkıran 2015.

14. In fact, post-Soviet traders' assessments were often ahistorical and localized. They homogenized diverse realities, especially for urban Turkish women, and assumed all Istanbullu women to be defined by gender structures framing the lives of many working-class Islamist women's lives (White 2004, 212-41).

15. This woman emphasized that when she herself had to fill out paperwork, she never wrote affirmatively that her mother had a criminal record.

16. There are wide differences between how private entrepreneurship was viewed across Eastern and Central Europe (ECE) and the former Soviet Union prior to 1989. Hungary was the first country to introduce market reforms in the late socialist period, and by the late 1970s select consumer goods were permitted for sale in the private sector, including in open-air markets (Williams and Baláž 2002, 325). Polish and Czechoslovak shoppers were attracted to these markets, and a thriving cross-border trade developed; by 1995 an estimated five hundred thousand people annually were crossing as small-scale traders out of Poland (Williams and Baláž 2002, 327). Given the tightly controlled borders of the Soviet Union, with passport controls in place until the early 1990s even for travel to 
the ECE, small-scale trade and informal markets were slower to develop there than in the ECE (Jerczynski 1999; Krassinets and Tiuriukanova 2001, 5).

17. In Dale Pesmen's account of sentiments about money in a post-Soviet Siberian city she quotes Jeffrey Brooks who writes of the Russian middle classes of the nineteenth century and their view of money: "Money [gained from business or commerce] ... although clearly sought after ... was regarded with ambivalence or hostility by much of Russian society, both because it was not old ... and because commerce and industry were associated with the exploitation of others" (Brooks 1985, 278; Pesman 2000, 126).

18. With the onset of perestroika in the late 1980s fleeting trade was allowed to operate throughout Eastern Europe with fewer restrictions, and as it expanded, vendors often spilled over from the vacant lots and historic town centers into city streets (Sik and Wallace 1999). In Russia in the early 1990s, these market areas, as well as other public spaces, were rapidly "privatized" as local governments sold off government property to the highest bidder, a process noted in the formation of market spaces across the former Soviet Union (Hohnen 2003). The degree of legality of trade has shifted depending on the political climate, those trading, what is being traded, and local deals being made between the new investors and city government officials. Today open-air marketplaces are generally legal in Russia, although close monitoring of market spaces persists, especially in relation to irregular migration into Russia (Humphrey 1999a, 90-95; Rabina 2000; Kramer 2007; Bloch 2014). For more on the history of shuttle trade and entrepreneurship in Russia, see Mukhina 2014.

19. For instance, Jennifer Patico writes of St. Petersburg teachers' discourses about "morally upright persons" as linked to the social usefulness of a given profession (2008, 140). Others have examined how private trade in late socialism was viewed as implicitly revealing the failure of the state provisioning system and reflecting bourgeois tendencies to desire consumer goods and accumulate capital (Verdery 1996; Kaneff 2002; Dunn 2004).

20. Marta Bruno argues that women's "need to provide material and emotional support" for their families is linked to their success as entrepreneurs and originates in the Brezhnev era when difficulties in obtaining basic goods "turned women into able managers and specialists of market operations" $(1997,62)$. Similarly, in her study of shuttle traders moving between Belarus and Latvia, Olga Sasunkevich points to material concerns as one of the key reasons for women being involved in trade, but she also highlights the different " "female' resources" women are uniquely able to draw on, including social networks and socially acceptable expressions of emotion at key moments, such as when officials demand customs duties at the border (2016, 165-66).

21. This period of "late socialism" and a "backlash" against Soviet policies officially promoting gender equality has been the subject of a vibrant feminist scholarship since the late Soviet era. For instance, in the late 1980s the LOTOS group (the League for Emancipation from Social Stereotypes), from which the Moscow Center for Gender Studies grew, analyzed four major forces in Russia (socialism, perestroika, democracy, and the emergence of market forms of exchange) from the perspective of gender equality and identified perestroika as a "period of postsocialist patriarchal renaissance" (Posadskaia 1994, 4).

22. While "shame," and its twin, "honor," have been the focus of a wide range of anthropological literature for nearly fifty years (for instance, see Pitt-Rivers 1965; Herzfeld 1980; and Wikan 1984), here I turn attention to how these ideas are socially and historically produced in the context of postsocialism.

23. This wide range of professional backgrounds among traders is consistent with Irina Badishtova's findings $(2002,84)$. Her survey on temporary labor migration (including shuttle trading) among households in five major Russian cities found that adult household 
members' past professions included teacher, lawyer, medical personnel, accountant, engineer, driver, and academic researcher.

24. Contrary to Badishtova's findings, where fewer than 10 percent of Russian households involved in labor migration had children under eighteen, the women in my sample were typically at a point in their life cycles where they had school-age children. Of the fifteen traders formally interviewed, all had children; two had grown children, and thirteen had children aged eight to eighteen. In fact, clothing and educating children are the primary reasons cited for becoming involved in trade.

25. In 2000 Olga had begun making weekly buying trips to Istanbul to fill out her inventory, including with chic silk blouses for $\$ 45$ and knit sweaters for more than $\$ 100$. In an economy where average monthly incomes at the time were \$300-400 per month in urban Russia, these clothes were within the reach of only a small segment of the population.

26. This phrase is borrowed from Anne Marie Leshkowich's work (2006) on textile traders in postsocialist Vietnam.

27. Through such institutions as museums, schools, and work units, state discourses on undesirable behaviors, and conversely on what it meant to be an upstanding citizen, indelibly shaped moral frameworks (Grant 1995; Bloch 2003a; Bloch and Kendall 2004), thus illustrating Foucault's much cited point that "discourses ... [are] ... practices that systematically form the objects of which they speak" $(1972,49)$.

28. According to opinion polls conducted in Russia in 2005 and published in the Moscow News, more than 60 percent of those over sixty years old thought Russia "needs a new Stalin," while 40 percent of all those polled agreed with this view; see Over $40 \%$ of Russians 2005. In another public opinion poll commissioned by the Carnegie Endowment nearly a decade later in Russia, Azerbaijan, Armenia, and Georgia, the results were somewhat more nuanced, but still the authors concluded, "deStalinization has not succeeded in the former Soviet Union and most post-Soviet citizens have not come to grips with their history" (Lipman et al. 2013, 1).

\section{CHAPTER 3. “WE ARE LIKE SLAVES-WHO NEEDS CAPITALISM?"}

1. Troitsa, or Pentecost, considered by the Eastern Orthodox Church to be one of the Orthodox "Great Feasts," second only to Easter, is celebrated seven weeks (or fifty days) after Easter. Troitsa is recognized widely in the former Soviet Union in regions with historically Christian populations as a holiday when one should spend time with family and possibly attend church. Sonja Luehrmann notes that in the Russian Volga Republic of Mari El, Christians were anxious about how their membership in a church community competed with the time required for their gardens $(2011,201)$. Perhaps in part due to similar demands on their time, many people I met in Gagauzia did not necessarily attend church services. However, even those who did not attend church services did gather with relatives and attend to family graves on Pentecost. In the early 1990s in the Evenk District in central Siberia I observed similar ritual practices related to Pentecost (2003a).

2. These farms occupied about 17 million hectares of cultivated land ( 34 million acres) and employed nearly 570,000 people. In 1993 Moldova had 600 collective farms (kolkhozy) that covered 16.2 million hectares of land and employed over 401,000 people, and 389 state farms (sovkhozy) on 600,500 hectares of land employing over 168,000 people (Fedor 1995). The main distinction between collective and state farms was that, with the former the workers collectively owned the land and equipment, relying on a redistribution of farm earnings, whereas with the latter workers were employed by the state and received regular salaries. In reality, except for those who continue to work on land reform, few people in the region today make a distinction. 
3. The average family was entitled to plots of land of 1.5 to 2.5 hectares, or about 3.3 to 6.8 acres (FAO 2001).

4. In 1996 remittances sent to Moldova via formal channels constituted just over 5 percent of the GDP, but by 2004 the International Monetary Fund (IMF) noted that 27 percent of Moldova's GDP consisted of remittances (Cuc et al. 2006, 2); in 2004 estimated remittances, including unofficially transferred sums, had reached $\$ 1$ billion (Ghençea and Gudumac 2004, 75). In 2009, 23.1 percent of Moldova's GDP was based on official remittances, giving Moldova the dubious distinction of occupying fourth place in the world for the level remittances played in the national economy, just behind Tajikistan, Tonga, and Lesotho with $35.1,27.7$, and 24.8 percent, respectively (UNDP 2011, 129). Significantly, unofficial transfers do not factor into these figures, and in 2005 the IMF estimated that as much as half of the remittances transferred were done so informally (Ratha 2005). Likewise, a study of remittances in Moldova based on a sample of 4,500 households, 715 of which had at least one family member abroad from January to September 2003, found that 56 percent of remittances were received through "informal" channels, meaning not wired into bank accounts or via Western Union money transfers (Ghençea and Gudumac 2004, 11, 74).

5. In 2004 the official population of Moldova was 4,439,000 people, and by 2010 it was down to $3,600,000$; in 2016 the population had dropped further to 3,553,056 (National Bureau of Statistics of the Republic of Moldova 2016). Numbers of those absent in labor migration have ranged from scholarly estimates of roughly 234,000 working-age adults in 2004 (Ghençea and Gudumac 2004, 41) to press accounts of as many as $1,600,000$ people. There is a great lack of clarity in the statistics, with length of absence, circular migration, and age of those absent just some of the factors that demand close scrutiny.

6. The highest levels of outmigration are found in smaller towns and rural areas. In 2004, of the official population of about seventeen thousand people in Vulcănești, nearly one-quarter of the active working-age population was documented as absent (Primeriia Vulkaneshty 2004). This was similar to other regional town centers across the country where, on average, in 2003, 22 percent of the active working-age population was absent in labor migration, in contrast to just over 9 percent of the working-age population absent from the capital city of Chişinaŭ (Ghençea and Gudumac 2004, 41).

7. For a classic ethnography about two collective farms in Buriatiia, see Humphrey $1999 b$.

8. Even by 2000, 83 percent of small farms and 60 percent of households with just subsistence plots were selling between one-third and one-half of their agricultural output. Farm households selling agricultural products made an average of $\$ 250$ per year more than those without surplus products to sell (Lerman 2004, 463, 467).

9. As a settlement for winning the Russo-Ottoman War, the Russian Empire demanded the creation of a large, autonomous Bulgaria; independent states of Serbia, Romania, and Montenegro; and the Russian takeover of Ottoman territory in the Caucasus and the Balkans (Reynolds 2011, 14). Ultimately, however, Great Britain, Germany, and AustriaHungary insisted on new peace accords (the Congress of Berlin), where a new settlement was forged. The 1878 Treaty of Berlin set out a transfer of Kars, Ardahan, and Batumi to Russia in place of the Ottomans paying reparations to Russia, and a smaller autonomous Bulgaria. Moreover, Russia was awarded only southern Bessarabia, a term Romania only agreed to as a price for having its independence recognized. For more on the negotiations around control of Bessarabia, see Anderson 1966, 202-12.

10. There is no consensus on the origins of the Gagauz. One theory traces Gagauz ancestors to the time of Genghiz Khan, linking them to the "Guz" or, according to the ancient Russian historical source of the letopis, to the Torks, a union of tribes that had ties to the Turkish Khanate (Ianyshev-Voloshin 1993, 5-12). Ianyshev-Voloshin argues 
that the Gagauz as a distinct group first appeared in the seventh century C.E. when they occupied the northern part of the steppe near the Aral Sea; along with other Torks, they presided over an immense territory with its center at Tuva. They thrived, in part, by virtue of their knowledge of metalworking, which gave them an advantage in defending and conquering territory, in cooperating with the Khazars, and in their location along the Silk Route (1993, 13, 27-29). According to this theory, by the tenth century the Guz moved westward and played a part in defending the outer reaches of the increasingly powerful Kievan Rus', a connection which Ianyshev-Voloshin credits with forging the first union between "Turkic-speaking nomads and Russian-speaking Slavs" (1993, 31-33). King, however, points to another predominant theory that the Gagauz originated with the Turkic Oğuz tribes inhabiting the area of Dobrogea (the western Black Sea coastal area of Dobrudja in present-day Romania and Bulgaria) in the early thirteenth century, when as subjects of Byzantium they converted to Orthodox Christianity $(2000,211)$.

11. Irina Subbotina found that 43 percent of the urban/town dwelling Gagauz she surveyed indicated that they spoke Russian better than Gagauz, while 36 percent of urban/ town dwellers said they spoke Gagauz better, and 17 percent said that they spoke each equally well. For urban Gagauz aged twenty to twenty-nine, however, nearly 50 percent indicated Russian as their better language, and for sixteen- to nineteen-year-olds about 60 percent indicated Russian as the language in which they had the greatest fluency (Subbotina 2007, 146). In contrast, rural Gagauz were more comfortable with the Gagauz language, with only 23 percent indicating they were more fluent in Russian than Gagauz, and 7 percent attesting that they spoke each language equally well. Generally, in 2007 the younger the person, the more fluently they tended to speak Russian, and the less comfortable they were in Gagauz (Subbotina 2007, 146-47).

12. Stepan Kuroglo and Maria Filimonova point to the lack of access to schooling and lack of voting rights for women under the Union of Bessarabia under Romania (1976, 22-23).

13. Transnistria, or the Prednestrovian Moldavian Republic, is located on the easternmost edge of Moldova, to the east of the Dniester River and bordering Ukraine. At a time between the two world wars, when most of the present-day Moldovan territory was part of Romania, Transnistria was part of the Soviet Union; in 1924 the Soviet Union designated the region as the Moldavian Autonomous Soviet Socialist Republic and governed it until 1990. In 1991 the majority of the population, which predominantly speaks Russian as a native language, voted in favor of independence and supported succession from the newly independent Moldova. Between 1991 and 1992 the state of Moldova asserted military force in its attempt to assert authority over the region, and Russia became involved in the conflict, threatening further military action if Moldova insisted on political control of the region. As of a July 1992 ceasefire Transnistria continues to be de facto autonomous from Moldova. However, internationally Transnistria is recognized as Moldovan territory. For more on this history, see King 2000 and Safonov 2014.

14. For an extensive treatment of the history of the Gagauz struggle for autonomy, and especially regarding language, see Demirdirek 2008.

15. As of January 2015 the Gagauz Autonomous Territory Administration reported the population of Gagauzia to be 155,656 people, with Gagauz accounting for 120,800 (82.1 percent) of the total population of the region. The remaining 18 percent of Gagauzian residents were Bulgarian (5.1 percent), ethnic Moldovan (4.8 percent), Russian (3.8 percent), or Ukrainian (3.2 percent) (Gagauz Autonomous Territory Administration 2015). This data was based on the 2004 census and with the extensive outmigration in the region over the past decade, including to Bulgaria and Romania, the percentage of Gagauz relative to other groups very likely increased. 
16. Of the 123,800 Gagauz counted in the All-Soviet Census in 1959, 96.4 percent were living in southern Moldova and bordering areas of Ukraine, but by 1989 of the 153,500 Gagauz, only 93 percent were concentrated in these regions (Subbotina 2005, 4, 6). Subbotina writes that by 2002, 22 percent of all those identifying as Gagauz within the areas of the former Soviet Union were living in Russia, mostly in the central parts of the country and in the Ural regions (Subbotina 2005, 10). The Gagauz Autonomous Territory Administration (2015) indicates that in addition to the Gagauz residing in Moldova, in 2004 there were over 40,000 Gagauz living just across the border in Ukraine, as well as sizeable populations living in other parts of Ukraine, Kazakhstan, Russia, Romania, Greece, Bulgaria, and Turkey (Gagauz Autonomous Territory Administration 2015).

17. In 2005 two-thirds of the population surveyed in Gagauzia indicated that they survived on less than $\$ 42.70$ per month; Subbotina reports that 6.8 percent of the population lived on less than $\$ 1.00$ per day $(2005,14)$.

18. Based on a sample of 715 households, Ghençea and Gudumac $(2004,49)$ found that the "very poor" (9.9 percent of their sample) who migrated had incomes increase over thirteen times what they were prior to migration, while the households with relatively "good" material circumstances (12.6 percent of their sample) had incomes increase just over four times what they were prior to migration.

19. Subbotina reported that 53 percent of all Gagauz she surveyed in Moldova aimed to depart for Russia $(2005,21-22)$.

20. In 2003 Ghençea and Gudumac found that of those Moldovans engaged in labor migration, 63 percent were men and 37 percent were women $(2004,44)$. Subbotina also writes that more men than women were leaving Moldova, specifically noting that twothirds of the "guest workers" (gastarbaitery) leaving Moldova were men (2007, 136).

21. For examples of typical media treatments of trafficking in women in Moldova, see Bell 2003 and Kirby 2004. Of the many journalistic accounts of trafficking in women from Moldova, William Finnegan's (2008) article provides useful context for understanding the situation.

22. The House of Culture was a fixture on the Soviet landscape and persists today in many communities in the former Soviet Union. As Joachim Habeck (2011) demonstrates, in Soviet times these organizations were central places for community events, recreation and artistic performances, and political meetings (see also Grant 1995).

23. According to Subbotina, in 2004 one in three Gagauz families had at least one household member abroad $(2007,136)$. In 2007, 50 percent of migrants from Gagauzia were in Russia, of which 23 percent were in Moscow. Just over one-third of Gagauz migrants (34 percent) were in Turkey, and 3 percent were in Ukraine. Another 1-2 percent of total Gagauz migrants were also in each of the following four countries: Italy, Germany, Spain, and Portugal. There were also Gagauz in the United States ( 3 percent of the migrants recorded in 2007) (Subbotina 2007, 138). There is a significant difference in the location of migrants depending on whether they originated in urban or more rural communities and whether they were men or women; 60 percent of the more urban Gagauz were in Russia and 32 percent in Turkey, while 53 percent of rural migrants were in Russia and 35 percent in Turkey (Subbotina 2007, 138). In all cases women overwhelmingly sought work in Turkey, and men in Russia.

24. I encountered two people who had won the right to immigrate to the United States via the Green Card Lottery; however, this was not a route widely discussed or one that affected many people in the town of Vulcanești. According to the US Department of State, each year the number of Moldovan citizens receiving visas through the Diversity Immigrant Visa Program, or "Green Card Lottery," grew steadily from 152 people in 2006 to 1,566 people in 2015 (US Department of State 2015). 
25. Following Russia's military intervention in Ukraine beginning in the spring of 2014, Eva and Andrei told me via Skype that southern Moldovans had become more tentative about crossing this border. Although people still traveled for twenty-four hours by minibus (rafik) via Ukraine to reach Moscow for work, stories circulated of some migrants having passports ripped in two by border guards and bribes required for crossing into Russia. The more unpredictable nature of the border regime meant that transnational shopping for foodstuffs became less common, and migrants often postponed travel between Russia and Moldova until they saved enough money to make the trip by air.

26. Of the fifty-three members of the governing coalition in power in Moldova in July 2010, nine of them had a second passport that was Romanian, and eleven more members had applied for a Romanian passport (Bidder 2010).

27. The number of Moldovans who identified as having Bulgarian heritage may have more than quadrupled through the 2000s; Bulgaria's Diaspora Minister Bozhidar Dimitrov claimed there were about 250,000 such people (Dimitrov Eager 2010), but according to the 2004 Moldovan census, there were just 65,662 Moldovan citizens who identified as having Bulgarian heritage (National Bureau of Statistics of the Republic of Moldova 2004). In 2010 one news source indicated that as many as 4.7 million people from Moldova, Macedonia, Serbia, Turkey, and Ukraine could apply for Bulgarian or Romanian citizenship by virtue of their claim to ethnic ties to one of these countries (Mutler and Jahn 2010).

28. Graham Camfield notes that by 1878 the "Stundists," a generic term that emerged in Russia to denote those dissenting from dominant religious practices, had divided into two primary groups: the evangelical Stundobaptists and the Neostundists, who did not adhere to the Baptist focus on organization and dogma and had more in common with either the rationalist or mystical directions found among Spiritual Christians (1990, 693).

29. The fluidity of religious belief in the area is reflected in the fact that the $2004 \mathrm{Mol}-$ dovan census noted 33,000 people identifying as Evangelical, although the number cited in 2012 by the Union of Evangelical Christian Baptists of Moldova was 19,578 (Sprinchana 2011; EBF 2012).

30. Non-Evangelicals in town casually referred to this secondhand store as the gumanitarka, or "humanitarian" store, often with a sense of dismissal. In 2011 the sign, in fact, featured a transliteration into Russian from the English term "secondhand" (sekond khend), and someone had also scribbled gumanitarka in Russian on the door.

31. In 2004 these plants together employed nearly 600 people, with one of the three plants employing nearly 450 of the total; all three had very high turnover (Gorodskoi otdel statistiki 2004).

32. The school principal noted that in 2004 it was common for children to be raised without one or both parents present; in the school's fifth grade class in 2004 nine of the twenty-four children were living with a grandparent or close family relative other than their parents.

33. Minibuses traveling between Vulcaneşti and Istanbul, via Bulgaria and Romania, departed several times each week, arriving at the minibus lot in Laleli. First-time migrants most often traveled by minibus or minibus and ferry. More-established migrants who could not afford to lose workdays and were taking short trips home from Istanbul usually flew. In 2013 a one-way ticket on the minibus cost about $\$ 75$, while one-way flights from Chişinaŭ were about $\$ 150$, and a seat on the ferry from Ukraine to Istanbul was about $\$ 80$. Until 2004, as Romania and Bulgaria restricted border crossing in preparation for their eventual EU accession, migrants were able to cross those countries' borders without any special visas and so most often traveled by minibus from Moldova through Romania and Bulgaria to Turkey. 
34. A number of scholars have pointed out the slippery nature of the term "household" (Stack 1974, 31; Yanagisako 1979). Here I likewise understand the idea of "household" to include not just those living under one roof but also extended ties between grown siblings, parents and children, grandparents and grandchildren, et cetera. The key is, as Carol Stack (1974) suggests, "those you can count on," not the specific people living under one roof.

35. It is not uncommon for households to include a married couple with ties to more than one ethnic community; however, since the end of the Soviet Union ethnic lines are increasingly demarcated and households I encountered tended to choose to ally, at least in narratives they shared with me, with one or another ethnic group's interests in the region.

36. Pensions are significant for household incomes in the former Soviet Union and Eastern Europe, including for households where children are being raised. For instance, of households with children six years old and under being raised in Albania, 39 percent included recipients of pensions, and in Moldova 29 percent of such households included a person receiving a pension (Stewart and Huerta 2009, 168).

37. Historically Gagauz practiced ultimogeniture, where the last born son inherited land and other property from the father, in addition to taking on the responsibility of caring for elderly parents. As Elizaveta Kvilinkova points out, while ultimogeniture was the ideal form of inheritance among Gagauz, at least until the 1950s, in reality it was not always practiced $(2007,209)$.

38. There were some apartment dwellers who had significant ties to farming. In some cases the offspring of those in single family dwellings lived in such apartments, and so sometimes took part in homestead production in their natal family's homesteads. For instance, Zina's daughter in the Kaloglo household told me that on completing her technical degree, she was given one such apartment. In the early 1990s the apartment was privatized for barely $\$ 50$. By 2005 this same apartment sold for $\$ 10,000$. (Zina's daughter quoted US dollar sums, rather than the Moldovan lei, a currency that was relatively unstable at the time.)

39. According to one study, remittances in Moldova made up 75 percent of the household budget for 27 percent of households that were caring for children and receiving remittances (Salah 2008, 5).

40. Keough also writes of washing machines as a new way for households to signify status in southern Moldova (Keough 2015, 61).

41. Staff at the regional hospital in southern Gagauzia told me how even with the privatization of medical care in Moldova in recent years it was still more affordable than it would be for foreigners seeking care in Turkey. With few people's employment in Moldova including adequate health insurance (strakhovoi polis), some people individually purchased a standard insurance plan that in 2004 cost about \$40/year (400 lei); only those who could afford more costly policies found the insurance really covered all their health care needs. See Rivkin-Fish 2011 on the privatization of health care and moral economies in Russia.

42. There was an especially sharp increase in divorce between 1990 and 2002, with only 77 divorces for the greater region in 1990, and 164 for the same region in 2002 (Raionnyi ZAGS 2002).

43. Although it was not impossible for men to take their mother's maiden name, or to take on their wife's surname, this was unusual. Cultural practice tended to mitigate against it. For instance, Zina's son was disgusted that his father had abandoned the family years earlier, and he did not want to have his father's surname. For months prior to actually submitting the necessary documents for receiving his identity papers at age sixteen, Zina's son told her he would not take his father's last name and would instead take his mother's maiden name. Ultimately, the social pressure and the hassle of having to gather 
all essential documents (birth certificate, school diploma, etc.) for reassessment meant that Zina's son kept his father's surname as his own.

\section{CHAPTER 4. STRATEGIC INTIMACY, “REAL LOVE," AND MARRIAGE}

1. The educational and professional backgrounds of women I came to know were generationally defined. Women under thirty had all completed high school and sought out work in an emerging service sector; among them, just one had graduated from university, with a law degree. Women in their thirties, forties, and fifties had all obtained postsecondary training-for instance, in electronics or nursing; three women had also completed university (and been working in their professions) prior to the end of the Soviet Union, one woman was a teacher, one an architect, and one an engineer.

2. As of 2009 the Province of Istanbul, synonymous with the Municipality of Istanbul, comprised thirty-nine districts, including Beyoğlu, Fatih, Şişli, Eminönü, and Zetinburnu (Genç and Özdemirkıran 2015, 109). Migrants' conversations were interspersed with reference to districts, for instance, when discussing travel for work in relatively distant destinations (e.g., Beykoz), as well as reference to neighborhoods, such as when they exchanged information about the geography of a handful of areas of the city (e.g., Taksim, Zetinburnu, Aksaray, or Laleli) that were familiar to most other long-term migrants I met.

3. According to one news source, in 2002 alone more than fifty thousand marriages took place between Turkish men and "Russian" women (Türkiye ve Rusya 2003), although this number is difficult to substantiate and seems inflated. Another news source cites a Turkish think tank, indicating that in 2016 there were as many as three hundred thousand "Turkish-Russian" married couples in Turkey (Nemtsova 2016).

4. Based in part on data from the Turkish Office of Population and Citizenship, Ministry of the Interior, İçduygu $(2009,289)$ calculates that between 2001 and 2005 nine hundred people gained citizenship by being naturalized, and almost all of them, presumably able to demonstrate ties to Turkish descent or culture, came from Balkan countries (Macedonia, Serbia and Montenegro, Bulgaria, and the Former Yugoslavia) and just three from Romania. As with many countries globally, Turkey strongly favors the jus sanguinus principle for granting citizenship, with an emphasis on "proving Turkish descent or culture" for citizenship to be granted (İçuygu 2009, 288).

5. A total of 56,449 people were granted Turkish citizenship between 1995 and 2000 (İçduygu 2009, 289), and those being granted citizenship came predominantly from seven countries (Bulgaria, Iran, Iraq, Romania, Russia, Azerbaijan, and Moldova).

6. As a stateless ethnic group Kurds are concentrated in a mountainous area stretching among Turkey, Armenia, Syria, Iraq, and Iran. As the fourth largest ethnic group identifying as Muslim in the Middle East, in 2016 they made up as much as 20 percent of the overall population of Turkey and Iraq, and as much as 10 percent of the Syrian and of the Iranian populations (BBC 2016b).

7. In tracing the histories of interaction between the Ottoman and Russian empires from just before and just after the world wars, Michael Reynolds (2011) also examines the intricacies of Russia's history of conflict and diplomacy with various groups of Kurds.

8. The novel Interdevushka or Intergirl (Kunin 1991), featuring a struggling nurse in late 1980s Leningrad who turns to prostitution with foreigners, is perhaps the most iconic portrayal of radically shifting gender terrain in the late Soviet Union. In 1989 the film based on the novel was by far the most popular film of that year in the Soviet Union. The book was translated into English in 1991.

9. For a compelling documentary on Russian women's use of matchmaking agencies in their efforts to find husbands from North America, see In the Name of Love (2002). 
10. The apartment I subleted in Istanbul during fieldwork in spring 2007 was no exception. A photograph of Kemal Atatürk posed in his swim suit hung by the apartment entrance.

11. Reynolds refers to "militant secularism" as a key element of the founding of the Turkish Republic in 1923 but notes "the Turkish Republic never dared turn its campaign against religion into an outright assault as the Soviet Union did" $(2011,260)$.

12. The AKP steadily increased its support over its first four terms in power, with nearly 34 percent of the vote in 2001, 47 percent in 2007, 50 percent in 2011, and 50 percent in 2015 (Taşpınar 2012; Henley et al. 2015). Notably, Prime Minister Erdoğan sought to signal the AKP's tempered association with Islam in describing his party's aims to establish "conservative democracy"; others have referred to the AKP's aims as "political Islam" (Taşpınar 2012). In an April 2017 referendum Prime Minister Erdoğan further consolidated power when just over 51 percent of voters affirmed their support for a constitutional change that would end the parliamentary system currently in place in Turkey and give a future president full control of the government (Kingsley 2017).

13. However, it would be a mistake to assume this as a fixed binary of ideational systems or a set of totalizing ideals. Feyda Sayan-Chengiz laments that women in headscarves get associated with a "fixed and reified identity" $(2016,3)$, and in her work among lowermiddle-class women wearing headscarves and working in the retail sector in Turkey, she aims to show the various forms of negotiation women in fact engage in as they weigh when to wear headscarves.

14. Though Natasha is a relatively common Russian name, beginning in the early $1990 \mathrm{~s}$ in Turkey the name became a term widely synonymous with "prostitute." One explanation for the widespread use of the epithet "Natasha" links it to a song popularized in the early 1990s (Béller-Hann 1995, 231-32).

15. Polina saw this man again after twenty years when he decided to marry and discovered that his divorce from Polina had not been properly processed. He and Polina had to hire lawyers and spend time in legal proceedings to affirm that they were, in fact, divorced.

16. There is a long tradition within the social sciences of examining the practices and meanings around marriage and intimacy (e.g., Giddens 1992; Kendall 1996; Hirsch 2003; Jankowiak 2008). This scholarship has shown that marriage practices are anything but static and instead are shaped by global economic flows, as well as new flows in media, people, and ideas about intimacy.

17. A number of scholars have written about contemporary marriage practices in Turkey. For instance, Kimberly Hart (2007) shows how arranged marriage and discourses on romance coexist in communities in eastern Turkey. For a challenge to modernization theories about the development of family forms and a brief historical review of urban and rural family forms in Turkey, see Vergin 1985.

18. Scholars have noted similar practices for other societies in the region at the time. For instance, see Manning 2015 on forms of "anti-marriage" that were historically practiced in Georgia, where until the mid-twentieth century mountain dwellers practiced forms of sexuality and romance that could never lead to marriage. Also see Haeri 2014 on the practice in Iran of "temporary marriage," an arrangement between a man and an unmarried woman in which they agree to be married for as long, or as short, as they wish the contract to last. Shahla Haeri also notes that Shi'a doctrine distinguishes between temporary marriage ( $m u t t$ 's), which is meant for sexual enjoyment, and "permanent marriage" (nice), meant for procreation $(2014,2)$.

19. Alan Duben and Cem Behar indicate that about 10 percent of high-ranking government officials in the late nineteenth and early twentieth centuries were polygynously 
married, although no more than 2.3 percent of Istanbul marriages overall were polygynous $(1991,156)$.

20. It was unusual that the case even went to court. During my fieldwork undocumented workers from the former Soviet Union were normally deported within twentyfour hours, following a brief period in the Istanbul detention center for foreigners (“yabancı şube").

21. Legislation passed in 2003 made employers liable for a fine of one billion Turkish lira for each undocumented worker they hired and subject to having their business license revoked (Narl1 2003, 34). In 2003 this was approximately $\$ 716$.

22. Ali paid the student $\$ 500$ a year to keep the marriage contract.

23. Like most of the women I met during the research who were working as shop assistants, Maria was paid in US dollars.

24. The amount migrants were required to pay in "exit fines" for overstaying tourist visas was regularly published in a bimonthly Russian- and Turkish-language newspaper distributed in Istanbul from 2004 to 2007. In 2007 the fines totaled 118 Turkish lira (about $\$ 89$ ) for overstaying by one month and 840 Turkish lira (about \$632) for overstaying by twelve months (Ugolok iurista 2007, 11). The fines for overstaying a work visa or for being employed without a work permit continued to change throughout the 2000s (Kocaoğlu 2012; Turkish Labor Law 2015).

\section{CHAPTER 5. INTIMATE CURRENCIES}

1. In 2002 as a newly arrived entertainer Kara earned \$18/day.

2. Kara used this term even though gambling was not a component of the nightclub's activities. However, Julie Scott (1995) writes of post-Soviet women working as croupiers in casinos in northern Cyprus, and I met one woman who had worked there, so it is possible that the reference to the Istanbul club as a "casino" has its origins in this migration trajectory.

3. A representative of the Istanbul based Human Resource Development Foundation (HRDF), an NGO focused on reproductive health and family planning education that also assisted in anti-trafficking training among Istanbul law enforcement, pointed out that the anti-trafficking measures policed women but were an inexact means of identifying who might be a victim of trafficking (Interview, June 2005).

4. Local regulations required regular tests for AIDS and other STIs in order to work as an entertainer in a club, but these requirements did not apply just to foreign entertainers. Turkish law also requires all Turkish women registered as sex workers and working in government-run brothels to receive regular screenings for gonorrhea, syphilis, AIDS, and Hepatitis-B. According to Şükran Şimşek et al., in 2003 Turkish sex workers were required to be screened for gonorrhea twice a week, and for syphilis and AIDS every three months, with each set of test results sent to the local police $(2004,58)$.

5. See Shankland 2003 on the strong presence of left-leaning political sentiments among the Alevi, a historically Shi' ite group and the largest religious minority in Turkey, a predominantly Sunni country. Alevi and Kurdish communities and their politics significantly overlap, although they are not synonymous (Mandel 2008, 271-87).

6. These themes resonated through visual culture as well as through official discourse. For a vivid portrayal of these ideals, see Bed and Sofa (1927). The groundbreaking film traces the lives of a Soviet worker and his wife in the rapidly industrializing center of Moscow and the challenge to gender paradigms as the couple is caught up in a ménage à trois, leading to questions about sexual propriety, abortion, and the purposes and implications of the institution of marriage.

7. Although a wide cross-section of the population did take part in these protests, undocumented workers I know from the former Soviet Union did not take part because they generally avoided spaces that could make them vulnerable to police. Taksim Square 
and the adjacent Gezi Park gained international visibility in summer 2013 when images of protesters clashing for weeks with police over plans to build a shopping complex in place of the park went viral on social media. As a popular leisure area for a wide cross-section of the Turkish public, protests in Gezi Park also came to catalyze protests across Turkey that called for political reform. See Yildırım and Navaro-Yashin 2013; Zengin 2013.

8. Entertainers explained that they were given a chit (fishka) for each drink a customer bought, and for each chit they received 2 lira. They complained that instead they should receive a percentage of the total a customer spent, since men's drinks could cost as much as 20-30 lira and women's 30-40 lira. (In the spring of 2007 one Turkish lira was equivalent to about 75 cents US.) In some clubs entertainers were also expected to reach a set number of total drink sales; if they did not reach this, they were fined.

9. In 2002 dancers in one Ukrainian group paid their manager a fee of about $\$ 10$ of each week's pay, and the Turkish manager $\$ 5$. After paying about $\$ 10 /$ night for their hotel room, women had just $\$ 18 /$ night take home pay. Although dancers paid fees in Turkey in lira, they calculated their expenses in both lira and US dollars.

10. By 2007 dancers were making about \$27/night plus tips, and the nightclub paid the majority of their hotel expenses. Dancers were still required to work six days a week and were expected not to take on any other jobs. The intermediaries continued to arrange employment for dance troupes. One manager described to me how he had teamed up with a former dancer to recruit women to dance in his club; over eight months they brought thirty women from Russia, and each woman paid a fee of $\$ 150$ for the assistance in arranging visas and job placement.

11. Aside from the fact that many of the young women I met had studied some ballet, it is worth noting how erotic dance and classical dance forms might intersect. Patricia Demers identifies a certain commonality, if not tension, between erotic dance and ballet. As she says, "Admittedly there are recognizable differences between working at a horizontal barre and a vertical pole, between wearing toe shoes and five-inch stilettos. But what connections exist between glissade, pas de chat, grand plié, and demi-plié and ... the smooth circular swivel of the hips of grind, and the various walks, leaps and struts of striptease?... Are there parallels_or parodies—of pirouette, deboulé, relevé and arabesque in the preening, snake moves, jumps, cartwheels and arched torsos of striptease?" $(2004,92)$.

12. One 2003 IOM-commissioned report on irregular migration and trafficking in women indicates that the Ministry of Tourism was issuing six-month "ballerina" visas at the time of publication (Erder and Kaşka 2003, 66). By 2005 these six-month visas were no longer available. Notably, other countries like Japan and Canada also had a visa category "entertainer" in place for at least a decade, until the late 2000s. On the Japanese entertainer visa, see Faier 2009 and on the Canadian entertainer visa, which was curtained in 2012, see McDonald et al. 2000; Citizenship and Immigration Canada 2014.

13. Given the lost wages due to intermediaries, it is not surprising that in 2002 one of the dancers decided to join with several others to arrange her next contract independently, without the cost of managers.

14. In 2016 a number of provisions were put into place in the first widespread revision to legislation since 2003 regarding the employment of foreigners in Turkey. A series of laws spells out the conditions under which employers may hire temporary workers (e.g., for seasonal labor, in the case of an employee's extended absence, etc.), the required terms of employment, and in International Workforce Law no. 6735, the fines payable for unlawfully employing a foreign worker (Turkish Labor Law 2016; Turkish Parliament 2016). Also, this legislation made it easier to hire highly educated and specialized foreign workers, although not in the intimate services sector. This legislation was on the heels of the Law on Foreigners and International Protection (Turkish Ministry of the Interior 2014). 
15. Hotels advertise on a wide array of websites, including "educational" ones like Learn4good.com, where positions are posted with descriptions that minimize the adult entertainment aspect of the job while retaining job titles that suggest duties with ambiguity around "entertainment." For instance, in 2013 the MTM Animation and Organization indicated in its company profile that it was "looking for animators, dancers with or without experience." However, the actual job description linked to this company profile noted that the "animator" would be: "organizing daily sport activities and games with hotel guest $[s i c]$ and their children and take part in the evening entertainment as well (mini disco, show time, guest relation) [sic]." The description also noted that the position required the "animator" (event coordinator) to work eight to ten hours a day, six days a week (Learn4good 2013a).

16. Interestingly, the very visible sex work and erotic entertainment that is part of tourism is almost completely elided in the growing literature on tourism (e.g., Içöz et al. 1998; Göymen 2000; Tucker 2007). See, however, Scott 1995 on sex work in northern Cyprus; and Agathangelou 2004 on sex work in Cyprus and the Mediterranean more generally.

17. Advertisements spell out many key terms of the potential position, and some are careful to position the status of the place of work. For instance, the advertisement placed by Marmaris Recruitment in 2013 indicated that their client was a " $5 *$ nightclub" and that the position would include accommodation in Izmir, pay " $\$ 1,000$ to $\$ 1,500$ per month, with bonus up to $\$ 400$ per month on drink sales," and provide work permits paid for via deductions from the monthly wages. The advertisement also noted twice that applicants must be "attractive with good physic [sic]" (Learn4Good 2013c).

18. Some advertisements in 2016 stipulated that a permit could be applied for after a "trial period" of work, with no specific number of weeks or months indicated, while a few also attested that positions would come with a work permit. The divergence around work permit availability suggests that many positions assume employees will work on tourist visas.

19. In 2007 Belarus continued to have one of the more restrictive border regimes of formerly Soviet countries, with exit visas periodically required for citizens to leave the country, and police registration required of most noncitizens within three days of arrival in the country, although citizens from most countries of the former Soviet Union were able to travel to Belarus without visas. As an indication of the frequency of illegal exchanges of money with officials at the Belarus border, the Belarus Customs and Immigration website notes that it is forbidden to "leave money in the documents presented for checking" (Ministry of Foreign Affairs of the Republic of Belarus 2016).

20. This dominant discourse was exemplified by the IOM and British Council sponsored workshop "Trafficking in Women" held in Istanbul, June 20, 2002, and attended by representatives of international NGOs and Turkish law enforcement.

21. The word "muzhateer" is not Russian but Turkish, or more specifically Ottoman Turkish, in origin. It seems that entertainers modified a word that may have a long history of use dating back to the Ottoman era in reference to relationships and locations of sexualized labor. The word "muzhateer" derives from the Ottoman Turkish word musaytır, which has three separate definitions (Osmanlica 2017). The first definition is "an overseer or protector," possibly implying "in place of" (kaim olmak) a male relative. The second definition is a synonym of musallat, a noun used for someone who is "imposing oneself on or obsessed with someone" (as in musallat olmak). The third definition is "someone who is commanding or governing another and insuring they act appropriately." When entertainers invoked the word "muzhateer" they appeared to be referencing the first definition and placing an emphasis on finding men who could "sponsor" them financially. I am thankful to Eda Cakmakci for her assistance in researching this issue. 
22. While few Turkish women frequented the clubs, tourist women sometimes did, so it was conceivable that lesbian liaisons could have formed between them and entertainers. However, among the women I came to know I heard of no such instances.

23. Pioneer camps, or summer camps run by the Soviet government and sometimes trade unions, were widely attended by young people in the late Soviet Union, and one of the most famous ones was Artek, located in Gurzuf, Ukraine, and operating from 1925 until 1990 (World of Children 2007). Sonia would have been too young to attend Artek, but she might have attended the international children's center that was established in its place with substantial subsidies provided by the Ukrainian government.

24. Women were the most visible actors among post-Soviet sex workers, but I also encountered a vibrant economy of masseurs. In at least one case, the masseur was hired to both do "body work" and be a kept man for the gay man who hired him.

\section{CHAPTER 6. “OTHER MOTHERS," GRANDMOTHERS, AND THE STATE}

1. I coined this phrase partly in contrast to Elspeth Graham et al.'s (2012) framework of a "transnational family nexus," which I see as focusing too narrowly on a single institution as key to caregiving for children. I was also inspired by Barry Hewlett's extensive research on father-infant bonding among the Aka, a community of hunter-gatherers living in the rain forests of the southern Central African Republic and northern CongoBrazzaville. Hewlett argues that father-infant bonding "is embedded within a cultural nexus-it influences and is influenced by a complex cultural system" $(2013,46)$, and he draws comparisons to North American and European models of father-infant bonding. Hewlett notes that while in the 1980s North American and European fathers typically held their infants ten to twenty minutes a day, Aka fathers held their infants about one hour during the day, as well as at least a quarter of the time once the sun went down $(2013,46)$, a practice Hewlett links to the high value Aka placed on egalitarianism and cooperation.

2. The number of women migrating into cities in the Soviet Union especially increased from the late 1920s to the early 1940s. Whereas in 1928 women constituted just 24 percent of the urban workforce, by 1940 women made up nearly 40 percent of the urban workforce (Lapidus 1978, 166). Still, in the tumultuous years of the early 1920s to the late 1930s — defined by famine, war, urbanization, and collectivization-men, and not women, predominantly left rural areas. Liubov Denisova indicates that in this period 30 percent of rural men left villages for urban areas, while only 9 percent of women left $(2010,74)$.

3. The Office for the Protection of Motherhood and Infancy, the OMM or OkhMatMlad (Okhrana materinstva i mladenchestva), which was intended to have divisions across the country, was one of the key proponents of creating new forms of mothercraft. The first head of the OMM, Alexandra Kollontai, widely known for her radical views on family and society, sought to establish an array of state provisions for child care that would make it possible for women to fully engage as worker-mothers (Waters 1992, 128).

4. According to a 1918 survey, of the provinces (gubernii) that responded 104 counties had set up preschools, and an equal number had not. Moscow Province was at the forefront of these efforts, with twenty-three kindergartens, eight day-care centers, and thirteen "summer playgrounds," or loosely supervised spaces where children would gather (Kirschenbaum 2001, 38). In Moscow alone in 1918 there were 5 kindergartens, 13 "colonies" and 51 playgrounds, and by 1919 the city had a combined total of 203 such organizations.

5. Even though in 1931 less than 8 percent of urban children and less than 2 percent of all children in the Soviet Union attended some sort of preschool institution, Kirschenbaum also cites Commissariat of Enlightenment statistics indicating an increase of more than 80 percent in the number of preschool institutions in place across the Soviet Union 
between 1929 and 1931 (2001, 138). Nevertheless, the overall number of institutions and child attendees in 1931 was actually lower than in 1921; in 1921 there were 4,785 preschool institutions and 247,701 attendees, whereas in 1931 there were 3,769 institutions and 222,216 attendees (Kirschenbaum 2001, 91, 138).

6. See Kirschenbaum for a sense of the tensions that existed between educators and official curriculum in the 1920s, including as they played out in specific kindergarten settings in Russia $(2001,113)$. Kirschenbaum shows how ideals around caring for and educating preschool children shifted both structurally and philosophically. She traces the emphasis on "free upbringing," meant to "liberate" children from the authority of teachers and inculcate creativity that had defined the first years of Bolshevik efforts to promote preschool education. She also shows how "socialist upbringing," which would focus on "'the development in the child of a materialist world-view and collective habits," prevailed in the second half of the 1920s $(2001,106-7)$. If free expression was central to preschool curricula in the first years after the revolution, by the late 1920s, structure and state ideology around "labor" and "society" mattered more.

7. Jean Ipsa also indicates that by 1940 there were 46,041 child-care centers in the Soviet Union (Ipsa 1994, 12), although it is unclear if "child care" refers to only preschool programs for three- to seven-year-olds, or to care for all children, infants to seven-yearolds, at which time children entered school.

8. During the Second World War a tax was even introduced for those households that were childless. At first, a tax of 5 percent of household income applied to all childless adults, and then, in 1957, this was revised so that just twenty- to fifty-year-old childless men paid the tax, as well as twenty- to forty-five-year-old childless women (Vedomost 1957, 531-32; Denisova 2010, 75).

9. As part of this massive investment in rural areas, by the late 1980 s nearly fifty thousand medical facilities offered rural women in Russia neonatal care, as well as pre- and postpartum care (Rossiiskii statisticheskii ezhegodnik 2002, 245).

10. The number of children in residential schools and facilities went from fewer than thirty thousand in 1917 to four hundred thousand in 1920 and to more than five hundred thousand in 1922 (Waters 1992, 128).

11. In countries such as Poland, Hungary, and Czechoslovakia with discourses and policies around mothercraft also inflected by a socialist past, debates continue about the ways in which the state should support mothers and children. Predominant maternalist thinking supports looking after the needs of mothers and children both as a social good and as a pronatalist measure in an era of falling birth rates, but as critics point out these policies also serve government interests as a safety valve for rising unemployment, and they contribute to growing gender inequality (Saxonberg and Szelewa 2007; Szelewa and Polakowski 2008; Glass and Fodor 2011).

12. In 2009 these payments were credited with producing the 7.7 percent increase in births from the previous year (Denisova 2010, 174-75; Rivkin-Fish 2010), and by 2013 Russia's birth rates surpassed those of the European Union (Nechepurenko 2014). Russia's birthrate was 1.7 in 2013, while the EU's was 1.6.

13. Unlike women remaining in Moldova, women who were absent as labor migrants were also not eligible to take advantage of the Moldovan government's maternity policy provision allowing for the benefit to be paid to a caregiver, such as a grandmother or aunt, in lieu of the mother (US Social Security Administration 2014, 212).

14. In 199225 percent of households surveyed in urban Russia consisted of a mother, children, and grandmother, and by 1996, 32 percent did; correspondingly, the portion of single mothers living alone with children fell from 56 percent in 1992 to 45 percent by 1996 (Lokshin et al. 2000, 2186-87). 
15. In 2004 there were six day-care centers with 688 children attending (Primeriia Vulkaneshty 2004).

16. As Irina Subbotina describes, the history of seasonal Gagauz labor migration from the 1950s onward, along with the deportation of nearly fourteen hundred Gagauz from southern Moldova during the Second World War, has led to Gagauz living dispersed across the former Soviet Union (2005, 9-12). In Maria's case, her mother migrated to Latvia in the 1950s for work and Maria was raised moving between family in Latvia and Gagauzia.

17. Bella's grandmother most likely arrived a little later than 1880, during the TurkishRussian War. As described by Ianyshev-Voloshin (1993, 37-38), this was a time when refugees fled from Bulgaria, then occupied by the Ottoman Empire, to arrive in Bessarabia, then a part of the Russian Empire's territory. Ianyshev-Voloshin describes how these refugees were Gagauz and Bolgars but also Greeks, Germans, Jews, Albanians, and others.

18. Kvilinkova describes a number of types of adoption that Gagauz, and possibly others in the region, have historically practiced and have specific terms for, including when children are adopted out to relatives or nonrelatives, informally or legally (2007, 217-22).

19. Given the timing featured in Bella's account, her mother's family could also have been deported to Central Asia, along with more than 1,376 Gagauz (Subbotina 2005, 9-12), as well as members of other ethnic groups suspected of collaborating with Germany during the Second World War. Reynolds notes that between 1935 and 1938, anxieties about state security drove the Soviet Union to carry out "ethnic cleansing operations" of deportation, arrest, or execution of about 800,000 people $(2011,261)$.

20. Among formerly socialist states, as of the mid-2000s Bulgaria had the most extensive social benefits for mothers and children. For instance, in 2009 nearly 80 percent of households with children six years old and under received either economic assistance or child benefits (Stewart and Huerta 2009, 165). In the same year a small fraction (15 percent) of households in Moldova with two- to six-year-olds received child benefits, and nearly 50 percent of households with children under eighteen months received universal child benefit payments. Significantly, however, the share that child benefits played in household incomes steadily diminished to a minuscule level with the contribution to overall average household income decreasing from 1.7 percent in 1995 to 0.3 percent in 2002 (Stewart and Huerta 2009, 164).

21 . For a comprehensive analysis of how maternity and paternity leaves and benefits are paid globally, see Heymann and McNeill 2013.

22. Kvilinkova goes on to describe how in the past the Gagauz term buuk (older) would also be added to "mother" to distinguish the biological mother from the relative caring for the child $(2007,221)$.

\section{CONCLUSION}

1. The Turkish government accused supporters of Fetullah Gulen, an Islamic cleric and former political ally of Prime Minister Erdoğan's, whose followers number as many as five million, of orchestrating the coup attempt. As of May 2017 more than 130,000 people in government, the military, the police, the media, and educational institutions had been removed from their positions, with 45,000 already jailed and many prosecutions still pending (Akınerdem 2016; Kingsley 2017). The Turkish government considered a number of apparently innocuous acts as evidence that could link someone to the Gulenist movement, including: having an account with Asya Bank, which was founded by the Gulenists; sending your children to a school associated with Gulen; being employed by 
a Gulen-affiliated organization or institution, such as a hospital or university; subscribing to the Gulen newspaper Zaman; or even having Gulen's books in your possession (Hansen 2017).

2. Turkey's March 2016 agreement with the EU to step up policing of refugee flows seeking to enter Europe in exchange for improved prospects of EU accession, and Erdoğan's November 2016 retaliation against the EU vote to curtail accession talks with Turkey due to Turkey's response to the failed coup, exemplify how this plays out in Eurasia (BBC 2016a).

3. In 2015 Russia began stepping up deportations, as well as demanding high fees for monthly registration of migrants and a language proficiency exam even for temporary labor migrants (Andreeva 2015). 